\title{
EFEKTIVITAS PENEMPATAN APARATUR SIPIL NEGARA (ASN) \\ DALAM MENINGKATKAN KINERJA PEGAWAI \\ DI BADAN KEPEGAWAIAN DAN PENGEMBANGAN SUMBER DAYA MANUSIA DAERAH (BKPSMD) KOTA TERNATE PROVINSI MALUKU UTARA
}

\author{
Oleh \\ Sri Rizka Do Karim1, \\ Tjahya Supriatna ${ }^{2}$, Andi Pitono ${ }^{3}$ \\ 1) Program Magister Terapan Studi Pemerintahan Daerah Institut Pemerintahan Dalam Negeri \\ ikhaiwi9@gmail.com \\ 2,3) Institut Pemerintahan Dalam Negeri
}

\begin{abstract}
$T^{\prime}$ he state civil apparatus is one of the important assets in government organizations, the apparatus does not only act as an object that must always get the attention and protection of the government but also acts as a subject that can determine the progress of a government organization. The government bureaucracy reform is one of the aspects that need to be considered so that the government can make improvements, reforms and fundamental changes to the administration of the government, so that the tasks and functions of government can be carried out wellthrough the support of qualified apparatus resources, but in reality, the bureaucratic reform has not been fully successful, which is in practice the structuring of the State Civil Apparatus do not appropriate in placing the position of an apparatus. Based on the facts, the writer is interested in conducting a research entitled The Effectiveness of Placement of State Civil Apparatus in Improving Apparatus Performance in the Civil Service and Human Resources Development Region of Ternate City, North Maluku Province. In this research the researcher used a qualitative descriptive method. The results of the research can be concluded that the process of apparatus placement in BKPSDMD Ternate City has not been effective, while the factors that influence it include knowledge mismatch factors, mismatch of experience with positions and factors limiting the quantity of human resources that meet certain job requirements. Keywords: effectiveness, placement, performance
\end{abstract}

\begin{abstract}
Abstrak
$\mathrm{A}$ paratur Sipil Negara (ASN) merupakan salah satu aset yang sangat penting dalam organisasi pemerintahan, aparatur tidak hanya berperan sebagai objek yang harus selalu mendapat perhatian dan perlindungan dari pemerintah melainkan juga berperan sebagai subjek yang dapat menentukan maju mundurnya suatu organisasi pemerintahan. Adapun reformasi bikrorasi pemerintahan salah satu aspek yang perlu diperhatikan agar pemerintah dapat melakukan perbaikan, pembaharuan dan perubahan mendasar terhadap penyelenggaraan pemerintah, sehingga tugas dan fungsi dapat terselenggara dengan baik, melalui dukungan sumber daya aparatur yang berkualitas, namun kenyataannya reformasi birokrasi belum sepenuhnya berhasil di mana pada praktiknya penataan Aparatur Sipil Negara
\end{abstract}


(ASN) belum tepat dalam menempatkan posisi jabatan seorang pegawai. Berdasarkan hal tersebut kemudian penulis tertarik untuk melakukan penelitian dengan judul Efektivitas Penempatan Aparatur Sipil Negara (ASN) dalam Meningkatkan Kinerja Pegawai di Badan Kepegawaian dan Pengembangan Sumber Daya Manusia Daerah Kota Ternate Provinsi Maluku Utara. Pada penelitian ini penulis menggunakan metode deskriptif kualitatif. Adapun hasil penelitian dapat disimpulkan bahwa proses penempatan pegawai di BKPSDMD Kota Ternate belum efektif, adapun fakto-faktor yang memengaruhinya meliputi faktor ketidaksesuaian prestasi akademik atau pendidikan dengan jabatan, ketidaksesuaian pengetahuan, ketidaksesuaian pengalaman dengan jabatan dan faktor keterbatasan kuantitas sumber daya manusia yang memenuhi persyaratan jabatan tertentu.

Kata kunci: efektivitas, penempatan, kinerja PENDAHULUAN

paratur Sipil Negara (ASN) merupakan

$\Delta$ salah satu aset yang sangat penting dalam organisasi pemerintahan, karena aparatur tidak hanya berperan sebagai objek yang harus selalu mendapat perhatian dan perlindungan dari pemerintah sekaligus berperan sebagai subjek yang dapat menentukan maju mundurnya suatu organisasi pemerintahan. Menurut Wasistiono (2007:39) Penyiapan sumber daya aparatur daerah perlu dilakukan karena kenyataannya menunjukkan bahwa kualitas sumber daya manusia di daerah otonom belum terlampau menjanjikan. Oleh karena itu, sebagai salah satu faktor internal yang strategis kualitas sumber daya manusia merupakan kunci utama yang dapat merubah berbagai kelemahan menjadi kekuatan serta mengubah tantangan menjadi peluang. Untuk dapat menangkap peluang yang terbuka di depan mata, maka upaya utama yang dilakukan oleh masyarakat dan pemerintah daerah adalah membangun sumber daya manusia yang berkualitas.

Reformasi bikrorasi pemerintahan salah satu aspek yang perlu diperhatikan antara lain kesiapan pemerintah untuk memberdayakan aparatur, sebagai langkah strategis guna membangun pemerintahan agar lebih efektif dan efisien. Hal itu dimaksudkan agar pemerintah dapat melakukan perbaikan, pembaharuan dan perubahan mendasar terhadap penyelenggaraan pemerintah, sehingga tugas dan fungsi dapat terselenggara dengan baik, dengan dukungan sumber daya aparatur yang berkualitas. Konsekuensi tersebut sebagaimana tertuang dalam Peraturan Presiden 81 Tahun 2010 tentang Grand Design Reformasi Birokrasi yang menyebutkan delapan area perubahan reformasi birokrasi yang mencakup; organisasi; tata laksana; peraturan perundang-undangan; sumber daya manusia aparatur; pengawasan; akuntabilitas; pelayanan publik; dan pola pikir (mind set) dan budaya kerja (culture set) aparatur.

Menurut Menteri Pendayagunaan Aparatur Negara dan Reformasi Birokrasi Pemerintah saat ini tengah bekerja keras melakukan penataan terhadap Aparatur Sipil Negara (ASN). Banyak kebijakan yang dikeluarkan guna mendisiplinkan para Pegawai Negeri Sipil (PNS). Pegawai di bidang administrative dianggap penyebab lemah kinerja PNS dibandingkan pegawai swasta. Jumlah PNS dianggap lebih besar karena itu pemerintah melakukan cara untuk merampingkan jumlah PNS dan memaksimalkan kemampuan yang ada. Kalau di swasta setiap unit dituntut target sementara di ASN dan PNS sangat berbeda. Karena KemenPAN RB sebuah kementerian bertanggung jawab di bidang itu maka saya fokus beberapa hal. Pertama sistem manajemen pekerja berdasarkan performance base management. Jadi tidak ada lagi PNS datang ke kantor tidak jelas targetnya. Manajemen kinerja akan berpengaruh terhadap tunjangan kinerja nanti. PNS tidak malas kalau malas akan dievaluasi, kalau tidak cocok ditindak, kalau 
tidak perlu kita turunkan pangkatnya. Tidak perlu khawatir jumlah PNS berkurang karena kita punya sumber daya manusia yang luar biasa banyak. Tamatan pendidikan kedinasan banyak dari Politeknik Imigrasi, STAN, IPDN, STTG. Sekarang kurikulum lagi dibuat, sekolah kader atau apakah namanya nanti. Jadi nanti yang tadinya kerjanya ngantuk-ngantuk setelah masuk itu punya apresiasi tidak ngantuk lagi kerjanya karena dikasih kerjaan sesuai spesialisasi.

Permasalahan yang sering terjadi pada Aparatur Sipil Negara (ASN) dalam penataan terhadap Aparatur Sipil Negara adalah tidak menempatkan pegawai di posisi jabatan atau jenis pekerjaan yang tepat. Berdasarkan filosofi "The right man on the right place", penempatan atau staffing merupakan hal yang sangat penting dalam manajemen sumber daya manusia dalam upaya meningkatkan Semangat Kerja pegawai juga meningkatkan kinerja organisasi. Meski proses ini tidak mudah namun apabila dilakukan melalui tahap dan proses yang benar maka proses menempatkan orang yang tepat pada posisi yang tepat akan terwujud.

Penempatan pegawai yang tidak efektif akan menimbulkan berbagai permasalahan seperti yang diungkapkan oleh Menteri Pendayagunaan Aparatur Negara dan

Reformasi Birokrasi. Permasalahan tersebut antara lain kurangnya pemahaman, pengetahuan dan keterampilan pegawai akan deskripsi pekerjaannya, dan secara psikologis kondisi tersebut akan menurunkan semangat pegawai. Pada akhirnya kondisi akan berdampak pada rendahnya kualitas hasil kerja yang akhirnya akan berdampak negatif pada kinerja organisasi secara keseluruhan.

Secara garis besar reformasi birokrasi adalah roh good governance yang wajib dijalankan oleh pemerintah baik di tingkat pusat maupun di daerah seperti halnya dalam Lingkungan Pemerintah Daerah Kota Ternate. Namun demikian, dalam praktiknya masih menemui berbagai kendala dalam pelaksanaannya. Hal itu sebagaimana pandangan Ombudsman Maluku Utara yang diberitakan Antara Maluku. Berdasarkan hasil survei pelayanan publik secara nasional di tiga daerah Provinsi Maluku Utara memiliki pelayanan publik sangat rendah dibanding daerah lainnya. "Ketiga daerah tersebut Pemerintah Provinsi Maluku Utara, Pemerintah Kota Ternate, dan Pemerintah

Kabupaten Halmahera Tengah", kata kepala Ombudsman Perwakilan Provinsi Maluku Utara, Sofyan Ali di Ternate. Dia menyebutkan, khususnya di Pemerintah Provinsi Maluku Utara, pada 2015 lalu tercatat standar pelayanan terburuk alias masuk dalam kategori zona merah sepanjang 2015, begitu juga terjadi di Pemerintah Daerah Halmahera Tengah.

Begitu pula, untuk Kota Ternate berdasarkan hasil survei nasional Pemerintah Kota Ternate, hanya Dinas Kependudukan dan Catatan Sipil (DUKcapil) yang memiliki tingkat kepatuhan pelayanan publik yang baik atau masuk pada kategori zona hijau. Selain, Dukcapil, Dinas Pendidikan, BP2SP dan Dinas Tata Kota dan Pertamanan (DTKP) serta Badan Kepegawaian daerah (BKD) Kota Ternate, masuk pada standar zona kuning, selebihnya itu semuanya masuk pada standar pelayanan terburuk atau masuk pada zona merah (www.antaramaluku.com 15 April 2016).

Proses pelayanan publik di Lingkungan Pemerintah Kota Ternate belum terselenggara secara optimal. Berdasarkan kajian melalui survei secara nasional bahwa untuk Pemerintah Kota Ternate hanya satu Satuan kerja perangkat Daerah yang masuk dalam zona hijau, yaitu Dinas Kependudukan dan Catatan Sipil kemudian terdapat empat Satuan Kerja Perangkat Daerah yang masuk dalam zona kuning di antaranya Dinas Pendidikan, BP2TSP, Dinas Tata Kota dan Pertamanan serta Badan Kepegawaian dan Pengembangan Sumber Daya Manusia Daerah (BKPSDMD), itu artinya sebagian besar Satuan Kerja Perangkat Daerah (SPPD) berada dalam zona merah atas standar 
pelayanan terburuk. Jika melihat antara pelayanan publik dengan manajemen sumber daya manusia tentu mempunyai kaitan yang sangat erat, hal ini dikarenakan penyelenggara pelayanan publik adalah sumber daya manusia itu sendiri.

Dengan dikeluarkannya UndangUndang Nomor 11 Tahun 1999 tentang Pembentukan Kota madya Ternate, maka secara administrasi wilayah Kota Ternate telah menjadi bagian dari Provinsi Maluku Utara dan sejak itulah geliat berbagai aktivitas perekonomian, pemerintahan, pembangunan, dan kemasyarakatan mengalami peningkatan yang sangat pesat. Pemerintah Kota Ternate memiliki visi "Memantapkan Terwujudnya Kota Ternate Berbudaya, Agamis, Harmonis, Mandiri, Berkeadilan dan Berwawasan Lingkungan", diakronimkan dengan Kota Ternate "Bahari Berkesan". Pemerintah Kota Ternate sendiri memiliki jumlah Aparatur Sipil Negara (ASN) sebanyak 4.854 orang, yang dikondisikan menurut pendidikan, golongan dan tingkat jabatan.

Komposisi aparat Pemerintah Kota Ternate berdasarkan tingkat pendidikan, golongan dan jabatan berjumlah 4.854 aparat. Dari keseluruhan kualifikasi aparat sebagaimana telah dijelaskan, jika dibandingkan dengan kebutuhan aparat dalam lingkungan Pemerintah Kota Ternate dapat dikatakan masih kurang. Dari sisi manajemen sumber daya manusia dalam konteks penempatan aparatur sipil negara pada organisasi pemerintah daerah dapat dikatakan belum memadai. Padahal penyediaan sumber daya aparatur yang berkualitas sesuai dengan yang dibutuhkan setiap unit kerja organisasi Pemerintah Daerah sangat diperlukan dalam rangka meningkatkan kinerja pegawai. Hal itu bisa dilihat pada tujuh unit organisasi yang kelebihan Aparatur di antaranya, yaitu Bagian Bina Kesejahteraan Sosial, Bagian Kehumasan, Bagian Umum dan Protokol, Dinas Pemberdayaan Perempuan dan Perlindungan Anak, Dinas Pertanian,
Sekretariat Dewan Perwakilan Rakyat Daerah dan Badan Pengelola Keuangan dan Aset Daerah, sedangkan unit organisasi yang lain masih membutuhkan aparatur atau bisa dikatakan kekurangan Aparatur Sipil

Negara (ASN). Hal ini dimaksudkan agar pembagian tugas sumber daya manusia di dalam organisasi dapat terukur atau dengan kata lain sesuai kebutuhan organisasi berdasarkan kemampuan yang dimiliki dari setiap aparat yang ada. Namun demikian hal itu belum terlaksana dengan baik karena sebagian jabatan struktural yang ada di lingkungan Pemerintah Daerah Kota Ternate sebagaimana yang tercantum dalam struktur organisasi belum terisi.

Penempatan kerja adalah suatu proses kegiatan yang dilakukan untuk menentukan seseorang pada posisi yang sesuai dengan formasi yang dibutuhkan. Artinya penempatan kerja pegawai dilakukan dalam rangka. Mengisi formasi yang disesuaikan dengan kemampuan, keterampilan dan keahlian pegawai (Soedjadi, 2001: 176). Secara empiris, dalam berbagai penelitian baik secara kualitatif maupun kuantitatif ditemukan bahwa efektivitas penempatan pegawai memiliki pengaruh positif terhadap kinerja pegawai khususnya Aparatur Sipil Negara. Pada penelitian yang dilakukan oleh

Asri Nur Fadilah, Abdul Hakim, Siswidiyanto (2015) ditemukan bahwa penempatan pegawai berpengaruh signifikan terhadap kinerja pegawai dan aspek kesesuaian kemampuan dengan pekerjaan memiliki pengaruh yang paling tinggi. Selanjutnya secara kualitatif, penelitian yang dilakukan oleh Isra Yuliana, Djumadi, dan DB Paranoan (2015) menemukan bahwa penempatan pegawai yang tidak efektif antara lain penempatan pegawai yang tidak sesuai dengan kompetensi dan kualifikasinya menyebabkan kinerja pegawai kurang mencapai hasil yang optimal.

Berdasarkan observasi awal penulis menunjukkan bahwa penempatan pegawai dalam meningkatkan kinerja pegawai yang diselenggarakan oleh BKPSDMD Kota 
Ternate, belum terlaksana dengan baik. Artinya bahwa proses penempatan seseorang pegawai dalam suatu jabatan struktural dan penempatan setiap aparat pelaksana pada unit organisasi belum dilakukan secara merata. Masih terdapat unit organisasi yang memiliki kelebihan aparat pelaksana, sementara ada unit organisasi lain yang kekurangan, sebagaimana yang telah dipaparkan di atas. Padahal organisasi Badan Kepegawaian dan Pengembangan Sumber Daya Manusia Daerah (BKPSDMD) merupakan penggerak, atau "jantung" bagi organisasi pemerintah daerah, sehingga hal tersebut berdampak pada tugas dan fungsi yang belum terselenggara secara optimal.

Demikian pula penempatan aparat belum sepenuhnya didasarkan pada kemampuan yang dimiliki, tetapi didasarkan pada kepentingan tertentu dari pejabat politik yang berkuasa. Artinya, bahwa keberadaan aparat yang ditempatkan dalam suatu jabatan struktural terutama pada eselon II dan III, lebih banyak didasarkan pada kepentingan tertentu, dan bukan didasarkan pada kompetensi yang dimiliki, sehingga tugas pokok dan fungsi yang dilaksanakan belum terselenggara sebagaimana yang diharapkan. Permasalahan yang lain dalam pengembangan sumber daya aparatur, yaitu masih terdapat pendistribusian pekerjaan yang tidak merata sehingga belum sesuai prinsip the right man on the right places. Beban kerja yang dilaksanakan oleh seorang pegawai yang dipandang mampu oleh pimpinan, jauh lebih berat daripada pegawai lainnya, sehingga sering terjadi sebagian pegawai bekerja overtime, sementara ada beberapa pegawai yang tidak mempunyai pekerjaan (sangat santai). Dengan demikian dapat dikatakan bahwa proses pengembangan aparatur belum terselenggara secara efektif sehingga belum mampu meningkatkan kinerja pegawai.

Fenomena yang disampaikan di atas sulit diabaikan, bahkan sebaliknya memiliki peran yang sangat penting dan penentu bagi berhasil dan sukses tidaknya suatu organisasi. Landasan pengembangan aparatur sangat berhubungan dengan keteraturan dalam penataan organisasi, terkait erat dengan penempatan pegawai secara jelas dan transparan di antara sumber daya yang tersedia. Dengan adanya penempatan kerja yang efektif diharapkan setiap pegawai dapat melaksanakan pekerjaan sesuai dengan porsi dan kemampuan yang dimiliki. Hal itu dimaksudkan untuk mencegah terjadinya kesenjangan dalam pelaksanaan pekerjaan kantor, yang dapat menimbulkan adanya rasa ketidakpuasan pegawai, sehingga tingkat pencapaian kinerja menjadi tidak maksimal.

Berdasarkan permasalahan yang dipaparkan harapan dari masyarakat terhadap pemerintahan pusat dan daerah dalam melaksanakan tugas pokok dan fungsinya sangat tinggi. Sehubungan dengan itu salah satu aspek yang menentukan keberhasilan kinerja Aparatur Sipil Negara adalah penempatan pegawai yang efektif. Penempatan pegawai yang efektif akan mendorong pegawai untuk memberikan kinerja yang optimal dalam melaksanakan tugas dan fungsinya sebagai aparatur pemerintahan yang memberikan pelayanan terhadap masyarakat sesuai dengan kemampuan dan keterampilannya.

\section{RUMUSAN MASALAH}

1. Bagaimana efektivitas penempatan Aparatur Sipil Negara dalam meningkatkan kinerja Badan Kepegawaian dan Pengembangan Sumber Daya Manusia Daerah Kota Ternate?

2. Faktor-faktor apa saja yang memengaruhi efektivitas penempatan kerja Aparatur Sipil Negara pada Badan Kepegawaian dan Pengembangan Sumber Daya

Manusia Daerah Kota Ternate? 


\section{KAJIAN PUSTAKA}

\section{Konsep Efektivitas}

\begin{abstract}
Menurut Robbins (1994:85) efektivitas dapat didefinisikan sebagai tingkat pencapaian organisasi atas tujuan jangka pendek (tujuan) dan jangka panjang (cara). Pemilihan itu mencerminkan konsistensi strategis, minat mengevaluasi, dan tingkat kehidupan organisasi. Selanjutnya menurut
\end{abstract}

Sigit (2003:2) mendefinisikan efektivitas sebagai "ukuran sejauh mana tujuan (organisasi) dapat dicapai". Sedangkan efektivitas menurut Westra (1989:147) adalah "suatu keadaan yang mengandung pengertian mengenai terjadinya sesuatu efek atau akibat yang dikehendaki". Kalau seseorang melakukan perbuatan dengan maksud tertentu yang memang dikehendaki, maka orang itu dikatakan efektif kalau menimbulkan akibat sebagaimana yang dikehendakinya. Jadi, jika organisasi tidak mampu mencapai tujuannya maka organisasi tersebut dapat dikatakan tidak efektif. Efektivitas pekerjaan pemerintah dikatakan berhasil apabila suatu tujuan atau sasaran yang telah dicapai sesuai dengan rencana atau efektif, tetapi belum tentu efisien. Pekerjaan pemerintah sekalipun tidak efisien dalam input dan output tetapi tujuannya adalah efektif sebab mempunyai efek atau pengaruh yang besar terhadap kepentingan masyarakat banyak baik dari segi ekonomi sosial dan politik.

\footnotetext{
Makmur (2011:6) mengemukakan bahwa "efektivitas berarti kegiatan dilakukan secara efektif di mana dalam proses pelaksanaannya senantiasa menampakkan ketepatan antara harapan yang kita inginkan dengan hasil yang dicapai. Maka dengan efektivitas dapat dikatakan sebagai ketepatan, harapan, implementasi dan hasil yang dicapai". Dari berbagai pendapat tentang efektivitas yang dikemukakan oleh para ahli di atas maka dapat disimpulkan bahwa yang menjadi penekanan dari pengertian efektivitas adalah pada pencapaian tujuan atau sasaran yang
}

telah direncanakan atau ditetapkan sebelumnya. Jika tujuan dapat dicapai maka organisasi atau pelayanan tersebut dapat dikatakan efektif, namun jika sebaliknya tujuan yang telah ditetapkan tidak tercapai maka organisasi atau pelayanan yang dilakukan oleh organisasi tersebut dikatakan tidak efektif.

\section{Penempatan Pegawai}

Pada prinsipnya, penempatan seorang pegawai harus sesuai dengan kemampuan atau keahliannya atau dikenal dengan istilah "The Right Man On The Right Place". Menurut Rivai dan Sagala (2011:198): penempatan kerja berarti mengalokasikan para pegawai pada posisi kerja tertentu. Pendapat lain dikemukakan oleh Mangkuprawira (2011:166) bahwa penugasan kembali dari seorang pegawai pada sebuah pekerjaan baru. Kegiatan penempatan dilakukan berdasarkan tindak lanjut (follow up) dari hasil seleksi yang telah dilaksanakan sebelumnya. Kegiatan ini perlu dilakukan secara terencana karena akan memengaruhi produktivitas dan loyalitas pegawai". Selanjutnya menurut Siswanto

(2012:162): "Proses pemberian tugas dan pekerjaan kepada tenaga kerja yang lulus seleksi untuk dilaksanakan sesuai ruang lingkup yang telah ditetapkan, serta mampu mempertanggungjawabkan segala risiko dan kemungkinan-kemungkinan yang terjadi atas tugas dan pekerjaan, wewenang serta tanggung jawabnya".

Menurut Yuniarsih dan Suwatno (2013:116) penempatan pegawai tidak hanya menempatkan saja, melainkan harus mencocokkan dan membandingkan kualifikasi yang dimiliki pegawai dengan kebutuhan dan persyaratan dari suatu jabatan atau pekerjaan

Berdasarkan pengertian para ahli di atas dapat disimpulkan bahwa penempatan pegawai baik pegawai baru dan pegawai lama pada posisi yang tepat dan haruslah mencocokkan kualifikasi pegawai dengan persyaratan jabatan, seorang pegawai juga 
harus bisa mempertanggungjawabkan segala risiko atas tugas yang diberikan kepadanya.

Menurut Yuniarsih dan Suwatno, penempatan pegawai terdiri dari dimensi dan indikator berikut:

1. Pendidikan

Pendidikan minimum yang disyaratkan, yaitu menyangkut:

a. Pendidikan yang seharusnya, artinya pendidikan harus dijalankan sesuai syarat

b. Pendidikan alternatif, yaitu pendidik an lain apabila terpaksa, dengan tambahan latihan tertentu dapat mengisi syarat pendidikan yang seharusnya.

2. Pengetahuan Kerja

Pengetahuan yang harus dimiliki oleh seorang tenaga kerja agar dapat melakukan kerja dengan wajar. Pengalaman kerja ini sebelum ditempatkan dan harus diperoleh pada ia bekerja dalam pekerjaan tersebut. indikatornya adalah pengetahuan mendasari keterampilan, peralatan kerja, prosedur pekerjaan, metode proses pekerjaan

3. Keterampilan Kerja

Kecakapan/keahlian untuk melakukan suatu pekerjaan yang hanya diperoleh dalam praktik. Indikator keterampilan kerja adalah:

a. Keterampilan mental, seperti menganalisis data, membuat keputusan, menghitung, menghafal, dan lain-lain.

b. Keterampilan fisik, dapat bertahan lama dengan pekerjaan yang dikerjakannya.

c. Keterampilan sosial, seperti memengaruhi orang lain, berpidato dan lainnya.

4. Pengalaman Kerja
Pengalaman seseorang tenaga kerja untuk melakukan pekerjaan tertentu. Pengalaman pekerjaan ini indikatornya adalah pekerjaan yang harus dilakukan.

\section{Kinerja}

Keberhasilan suatu organisasi bergantung pada kinerja anggota dalam organisasi tersebut, kinerja menempati posisi yang penting dalam manajemen dan organisasi. Semakin baik kinerja anggota dalam suatu organisasi maka semakin cepat pula tujuan organisasi akan tercapai dengan baik. Menurut Mahsun (2014: 25) Kinerja (performance) adalah gambaran mengenai tingkat pencapaian pelaksanaan suatu kegiatan/program/kebijakan dalam mewujudkan sasaran, tujuan, misi dan visi organisasi yang tertuang dalam strategic planning suatu organisasi. Istilah kinerja sering digunakan untuk menyebut prestasi atau tingkat keberhasilan individu maupun kelompok individu. Kinerja bias diketahui hanya jika individu atau kelompok individu tersebut mempunyai kriteria keberhasilan yang telah ditetapkan. Kriteria keberhasilan ini berupa tujuan-tujuan atau target- target tertetu yang hendak di capai. Tanpa ada tujuan atau target, kinerja seseorang atau organisasi tidak mungkin dapat diketahui karena tidak ada tolak ukurnya.

Menurut Schermerhon dalam Uno dan Lamatenggo (2012: 121) bahwa "kinerja adalah kuantitas dan kualitas prestasi tugas dari seseorang atau kelompok". Sementara itu menurut Bernardin dan Russel dalam Uno Lamatenggo (2012: 122) mengemukakan definisi kinerja sebagai "catatan yang diperoleh dari pelaksanaan fungsi pekerjaan atau kegiatan tertentu selama suatu periode waktu tertentu".

Definisi kinerja dapat mengarah pada hasil kerja seorang pegawai. Sebagaimana dikemukakan Wilson dan Rosenfeld dalam Uno dan Lamatenggo (2012: 120) yang menyatakan bahwa "kinerja sebagai hasil dari seorang pegawai". Definisi serupa juga dikemukakan oleh Cascio dalam Uno dan 
Lamatenggo (2012: 120) yang menyatakan bahwa "kinerja merujuk pada keberhasilan karyawan terhadap tugas-tugas yang diberikan".

Menurut miner dalam Sudarmanto (2009:11) terdapat empat dimensi yang dapat dijadikan indikator menilai kinerja, yakni:

1. Kualitas, yaitu tingkat kesalahan, kerusakan, kecermatan.

2. Kuantitas, yaitu jumlah pekerjaan yang dihasilkan.

3. Penggunaan waktu dalam kerja, yaitu tingkat ketidakhadiran, keterlambatan, waktu kerja efektif/jam kerja hilang.

4. Kerja sama dengan orang lain dalam bekerja.

Pada dasarnya suatu organisasi terlebih organisasi pemerintahan, jika ingin maju atau berkembang sesuai dengan dinamika perkembangan dan tuntutan kebutuhan masyarakat, maka dituntut untuk memiliki pegawai yang berkualitas. Pegawai yang berkualitas adalah pegawai yang kinerjanya dapat memenuhi target atau sasaran yang ditetapkan oleh perusahaan. Untuk memperoleh pegawai yang memiliki kinerja baik maka diperlukan penerapan kinerja. Ukuran kinerja dapat dilihat dari sisi jumlah dan mutu tertentu sesuai dengan standar yang telah ditetapkan oleh organisasi atau perusahaan bentuknya dapat bersifat tangible (dapat ditetapkan alat ukurnya atau standarnya) atau intangible (tak dapat ditetapkan alat ukurnya atau standarnya), tergantung pada bentuk dan proses pelaksanaan pekerjaan itu.

Kinerja yang dihasilkan oleh pegawai dalam suatu organisasi ditentukan oleh beberapa faktor dan kondisi yang baik itu yang berasal dari dalam diri pegawai ataupun yang berasal dari luar individu pegawai.

\section{METODE PENELITIAN}

Dalam penelitian ini peneliti memakai desain penelitian deskriptif kualitatif untuk mendalami tingkat efektivitas Penempatan Aparatur Sipil Negara (ASN) pada Badan Kepegawaian dan Pengembangan Sumber Daya Manusia Daerah Kota Ternate. Peneliti berusaha mendapatkan gambaran dari keadaan yang berlangsung secara konkret sehingga dapat memperoleh data yang akurat untuk menganalisis fenomena yang diamati.

Efektivitas penempatan Aparatur Sipil Negara (ASN) dianalisis dengan menggunakan empat indikator utama menurut Yuniarsih dan Suwatno (2013) antara lain pendidikan, pengetahuan, keterampilan dan pengalaman. Hasil analisis tersebut diharapkan akan memunculkan temuan-temuan baru di lapangan, baik yang berupa fakta empiris baru, teori baru atau memperkuatkan teori yang telah ada.

\section{HASIL PENELITIAN DAN PEMBAHASAN}

\section{Efektivitas Penempatan Aparatur Sipil Negara dalam Meningkatkan Kinerja BKPSMD Kota Ternate}

Undang-Undang No. 5 Tahun 2014. Berdasarkan undang-undang tersebut penempatan aparatur negeri sipil (ASN) diatur dalam undang-undang. Pegawai ASN terdiri dari PNS dan PPPK. PNS merupakan pegawai ASN yang diangkat sebagai pegawai tetap oleh Pejabat Pembina Kepegawaian dan memiliki nomor induk pegawai secara nasional. Sedangkan PPPK adalah pegawai ASN yang diangkat sebagai pegawai dengan perjanjian kerja oleh pejabat Pembina kepegawaian sesuai kebutuhan instansi pemerintah dan ketentuan Undang-undang. Secara umum Pegawai ASN memiliki fungsi sebagai pelaksana kebijakan publik, pelayan publik serta perekat dan pemersatu bangsa. Menurut Undang-Undang No. 5 Tahun 2014, jabatan ASN terdiri dari tiga golongan jabatan berikut ini. 


\section{a. Jabatan administratif}

Jabatan administratif terdiri dari tiga kelompok, yaitu jabatan administrator, jabatan pengawas dan jabatan pelaksana. Pejabat dalam jabatan administrator bertanggung jawab memimpin pelaksanaan seluruh kegiatan pelayanan publik serta administrasi pemerintahan dan pembangunan. Pejabat dalam jabatan pengawas bertanggung jawab mengendalikan pelaksanaan kegiatan yang dilakukan oleh pejabat pelaksana. Pejabat dalam jabatan pelaksana bertanggung jawab melaksanakan kegiatan pelayanan publik serta administrasi pemerintahan dan pembangunan. Setiap jabatan ditetapkan sesuai dengan kompetensi yang dibutuhkan.

\section{b. Jabatan fungsional}

Jabatan fungsional dalam ASN terdiri atas jabatan fungsional keahlian dan jabatan fungsional keterampilan. Jabatan fungsional keahlian meliputi ahli utama, ahli madya, ahli muda dan ahli pertama. Selanjutnya jabatan fungsional meliputi penyelia, mahir, terampil, dan pemula.

\section{c. Jabatan pimpinan tinggi.}

Jabatan pimpinan tertinggi meliputi jabatan pimpinan tinggi utama, jabatan pimpinan tinggi madya, dan jabatan pimpinan tinggi pratama. Jabatan pimpinan tinggi berfungsi memimpin pegawai ASN pada instansi pemerintahan melalui:

- Kepeloporan dalam bidang keahlian profesional. Analisis dan rekomendasi kebijakan dan kepemimpinan manajemen.

- Pengembangan kerja sama dengan instansi lain
- Keteladanan dalam mengamalkan nilai dasar ASN dan melaksanakan kode etik dan kode perilaku ASN.

Untuk setiap jabatan pimpinan tinggi ditetapkan syarat kompetensi, kualifikasi, kepangkatan, pendidikan dan pelatihan, rekam jejak jabatan dan integritas, serta persyaratan lain yang dibutuhkan. Selanjutnya, menurut Sekretariat Kabinet Republik Indonesia terdapat persyaratan Pendidikan, pengetahuan, keterampilan serta pengalaman bagi jabatan pimpinan tinggi sebagai berikut.

\section{JPT Utama:}

1. memiliki kualifikasi pendidikan paling rendah sarjana atau diploma IV;

2. memiliki kompetensi teknis, kompetensi manajerial, dan kompetensi sosial kultural sesuai standar kompetensi Jabatan yang ditetapkan;

3. memiliki pengalaman Jabatan dalam bidang tugas yang terkait dengan Jabatan yang akan diduduki secara kumulatif paling singkat selama sepuluh tahun;

4. sedang atau pernah menduduki JPT madya atau JF (Jabatan Fungsional) jenjang ahli utama paling singkat dua tahun;

5. memiliki rekam jejak Jabatan, integritas, dan moralitas yang baik;

6. usia paling tinggi lima puluh delapan tahun; dan

7. sehat jasmani dan rohani.

\section{JPT Madya}

1. memiliki kualifikasi pendidikan paling rendah sarjana atau diploma IV;

2. memiliki kompetensi teknis, kompetensi manajerial, dan kompetensi sosial kultural sesuai standar kompetensi jabatan yang ditetapkan;

3. memiliki pengalaman jabatan dalam bidang tugas yang terkait dengan 
Jabatan yang akan diduduki secara kumulatif paling singkat selama tujuh tahun;

4. sedang atau pernah menduduki JPT pratama atau JF jenjang ahli utama paling singkat dua tahun;

5. memiliki rekam jejak Jabatan, integritas, dan moralitas yang baik;

6. usia paling tinggi lima puluh delapan tahun; dan

7. sehat jasmani dan rohani.

\section{JPT Pratama}

1. memiliki kualifikasi pendidikan paling rendah sarjana atau diploma IV;

2. memiliki kompetensi teknis, kompetensi manajerial, dan kompetensi sosial kultural sesuai standar kompetensi jabatan yang ditetapkan;

3. memiliki pengalaman jabatan dalam bidang tugas yang terkait dengan jabatan yang akan diduduki secara kumulatif paling kurang selama lima tahun;

4. sedang atau pernah menduduki Jabatan administrator atau JF jenjang ahli madya paling singkat dua tahun;

5. memiliki rekam jejak jabatan, integritas, dan moralitas yang baik;

6. usia paling tinggi lima puluh enam tahun; dan

7. sehat jasmani dan rohani.

Sementara itu, persyaratan untuk dapat diangkat dalam JPT dari kalangan non-PNS adalah sebagai berikut.

1. warga negara Indonesia;

2. memiliki kualifikasi pendidikan paling rendah pascasarjana;

3. memiliki kompetensi teknis, kompetensi manajerial, dan kompetensi sosial kultural sesuai standar kompetensi jabatan yang ditetapkan;
4. memiliki pengalaman jabatan dalam bidang tugas yang terkait dengan jabatan yang akan diduduki secara kumulatif paling singkat lima belas tahun;

5. tidak menjadi anggota atau pengurus partai politik paling singkat lima tahun sebelum pendaftaran;

6. tidak pernah dipidana dengan pidana penjara;

7. memiliki rekam jejak jabatan, integritas, dan moralitas yang baik;

8. usia paling tinggi lima puluh delapan tahun;

9. sehat jasmani dan rohani; dan

10. tidak pernah diberhentikan tidak dengan hormat dari PNS, prajurit Tentara Nasional Indonesia, anggota Kepolisian Republik Indonesia atau pegawai swasta.

Ketentuan yang sama juga berlaku bagi non-PNS yang akan mengisi JPT Madya, kecuali persyaratan memiliki pengalaman selama sepuluh tahun.Menurut Peraturan Pemerintah No. 11 Tahun 2017, pengisian JPT utama dan JPT madya dilakukan pada tingkat nasional. Sementara Pengisian JPT pratama dilakukan secara terbuka dan kompetitif di kalangan PNS sesuai dengan persyaratan. Pengisian JPT pratama sebagaimana dilakukan secara terbuka dan kompetitif pada tingkat nasional atau antar kabupaten/ kota dalam satu provinsi. Adapun pengisian JPT utama dan JPI madya tertentu yang berasal dari kalangan non-PNS harus terlebih dahulu mendapat persetujuan Presiden serta ditetapkan dalam Keputusan Presiden. Untuk pengisian JPT utama yang memperoleh hakhak keuangan dan fasilitas lainnya setara menteri, menurut PP ini, diiakukan melalui seleksi terbuka dan kompetitif sesuai sistem merit dan diangkat oleh Presiden. Dalam hal terjadi penataan organisasi Instansi Pemerintah yang mengakibatkan adanya pengurangan JPT, menurut PP ini, penataan Pejabat Pimpinan Tinggi dapat dilakukan melalui uji kompetensi dari pejabat yang ada oleh 
panitia seleksi. Dalam hal pelaksanaan penataan Pejabat Pimpinan Tinggi sebagaimana dimaksud tidak memperoleh calon pejabat pimpinan tinggi yang memiliki kompetensi sesuai, pengisian JPT dilakukan melalui Seleksi Terbuka.

Peraturan Pemerintah No. 11 Tahun 2017, juga menegaskan, pengisian JPT yang lowong melalui mutasi dari satu JPT ke JPT yang lain dapat dilakukan melalui uji kompetensi dari pejabat yang ada. Pengisian JPT sebagaimana dimaksud harus memenuhi syarat:

a. satu klasifikasi Jabatan;

b. memenuhi standar kompetensi Jabatan; dan

c. telah menduduki Jabatan paling singkat dua tahun dan paling lama lima tahun.

Selanjutnya, pada Undang-Undang No. 5 Tahun 2014 diatur mengenai manajemen PNS yang meliputi:

- Penyusunan dan penetapan kebutuhan

- Pengadaan

- Pangkat dan jabatan

- Pengembangan karier

- Promosi

- Mutase

- Penilaian kinerja

- Penggajian dan tunjangan

- Penghargaan

- Disiplin

- Pemberhentian

- Jaminan pension dan jaminan hari tua

- Perlindungan

Terkait penempatan ASN, tahapan awal yang harus dilakukan adalah penyusunan kebutuhan jumlah dan jenis jabatan PNS berdasarkan analisis jabatan dan analisis beban kerja. Penyusunan kebutuhan tersebut dilakukan untuk jangka waktu lima tahun dan diperinci per satu tahun berdasarkan prioritas kebutuhan. Pengadaan PNS merupakan kegiatan untuk mengisi kebutuhan Jabatan Administrasi dan/atau Jabatan Fungsional dalam suatu Instansi Pemerintah. Setiap instansi pemerintah wajib merencanakan pengadaan pelaksanaan pengadaan PSN. Kebutuhan akan jabatan PNS harus diumumkan secara terbuka kepada masyarakat oleh setiap instansi pemerintah dan setiap warga negara Indoensia mempunyai kesempatan yang sama untuk melamar menjadi PNS sesuai dengan persyaratan.

Penyelenggaraan seleksi pengadaan PNS oleh Instansi Pemerintah melalui penilaian secara objektif berdasarkan kompetensi, kualifikasi, dan persyaratan lain yang dibutuhkan oleh jabatan. Seleksi pengadaan PNS terdiri dari tiga tahap antara lain seleksi administrative, seleksi kompetensi dasar dan seleksi kompetensi bidang.

Selanjutnya, peserta yang lolos seleksi diangkat menjadi calon PNS yang ditetapkan dengan keputusan pejabat pembina kepegawaian. Calon PNS wajib mengikuti masa percobaan yang dilaksanakan melalui proses pendidikan dan pelatihan terintegrasi untuk membangun integritas moral, kejujuran, semangat, motivasi nasionalisme, kebangsaan, karakter kepribadian yang unggul dan bertanggung jawab dan memperkuat profesionalisme serta kompetensi bidang.

Masa percobaan tersebut dilaksanakan selama satu tahun. Selanjutnya calon PNS dapat diangkat menjadi PNS apabila memenuhi persyaratan sebagai berikut.

\begin{tabular}{lll} 
- Lulus & \multicolumn{1}{c}{ Pendidikan dan } \\
pelatihan - & Sehat jasmani dan \\
rohani. &
\end{tabular}

Pada dasarnya, penempatan kerja aparatur negeri sipil harus dilakukan sesuai prosedur yang telah ditetapkan. Prosedur penempatan kerja merupakan suatu urutan kronologis untuk menempatkan pegawai yang tepat pada posisi yang tepat pula. 
Prosedur penempatan kerja yang diambil merupakan output pengambilan keputusan yang dilakukan berdasarkan pertimbangan rasional maupun berdasarkan pertimbangan objektif ilmiah (Siswanto (2012:164). Berdasarkan pendapat tersebut, dalam Undang-Undang No. 5 Tahun 2014 telah diatur sedemikan rupa serangkaian tahapan dalam pengadaan dan penempatan pegawai mulai dari penyusunan dan penetapan kebutuhan pegawai, pengadaan, proses seleksi hingga tahap pengangkatan. Pada tahap seleksi terdapat persyaratanpersyaratan yang harus dipenuhi baik dari aspek Pendidikan, keterampilan, dan juga sikap. Setiap warga negara Indonesia berhak memperoleh kesempatan dan proses penempatan pegawai harus dilakukan secara adil dan objektif.

Berdasarkan wawancara dengan Kepala BKPSDMD Kota Ternate diperoleh keterangan bahwa prosedur penempatan kerja aparatur negara secara umum telah mengikuti Undang-Undang namun tingkat kesesuaiannya baru mencapai 60\% dikarenakan oleh berbagai faktor. Salah satu faktor yang menyebabkan prosedur penempatan yang kurang efektif adalah faktor ketersediaan sumber daya manusia yang sesuai kualifikasi.

Sesuai dengan penelitian yang dilakukan oleh penulis yang membahas terkait efektivitas penempatan ASN yang berada dalam Badan Kepegawaian dan Pengembangan Sumber Daya Manusia Daerah Kota Ternate, maka kemudian untuk menganalisis hal tersebut penulis mengacu pada teori yang dikemukakan oleh Siswanto (2002) yang menyebutkan beberapa aspek yang memengaruhi di antaranya aspek pendidikan, pengalaman, dan keterampilan.

\section{Aspek Pendidikan}

Pendidikan merupakan salah satu faktor dan syarat penting dalam penempatan pegawai. Secara ideal, seharusnya setiap pegawai dalam melaksanakan tugasnya harus selaras antara tingkat pendidikan dengan jenis pekerjaan. Seperti yang disampaikan oleh Siagian (2001: 112), bahwa dalam rangka mendorong motivasi pegawai untuk peningkatan kinerja manakala pegawai yang bersangkutan ditempatkan pada posisi yang tepat atau ada keselarasan antara tingkat pendidikan dengan jenis pekerjaan. Penempatan pegawai berdasarkan tingkat pendidikan Ini berarti pegawai harus ditempatkan pada posisi yang tepat atau selaras antara tingkat pendidikan dengan jenis pekerjaan, maka pegawai lebih terpacu untuk meningkatkan kinerja. Oleh karena itu penempatan pegawai hendaknya diselaraskan antara tingkat pendidikan dengan jenis pekerjaan, sehingga pegawai dapat lebih berkembang dan lebih kreatif.

Berdasarkan wawancara dengan Kepala Badan Kepegawaian dan Pengembangan Sumber Daya Manusia Daerah Kota Ternate bahwa pengisian jabatan pada BKPSDMD Kota Ternate saat ini sudah sesuai dengan pangkat dan golongan para pegawai yang ada, di mana telah kami sesuaikan dengan Daftar Urut Kepangkatan (DUK) pegawai yang telah ada sehingga tidak ada masalah, masalah yang kami hadapi saat ini hanyalah kurangnya pegawai untuk mengisi jabatan yang kosong sebanyak 20 jabatan termasuk di dalamnya bagi eselon IV dan jabatan fungsional umum serta beberapa kualifikasi pendidikan karena kita tahu bahwa belum banyak pegawai yang mampu melanjutkan sekolah pada tingkat lebih tinggi, sementara ini pegawai berpendidikan S-1 sebanyak 14 orang dan S-2 sebanyak 3 orang yang ada pada BKPSDMD Kota Ternate."

Dari hasil wawancara di atas dapat disimpulkan bahwa, penempatan kerja Aparatur Sipil Negara (ASN) pada BKPSDMD Kota Ternate ditinjau dari aspek kesesuaian Pendidikan dengan jabatan belum efektif.

Hal tersebut dikarenakan 65 jabatan tidak terisi penuh karena jumlah pegawai riil hanya berjumlah 45 orang, kemudian pada pengisian jabatan sudah sesuai dengan Daftar Urut Kepangkatan (DUK) pegawai, hanya saja pada tingkat pendidikan belum 
mencapai sasaran karena pada tingkat pendidikan, hanya terdapat 14 orang dengan jenjang S-1 dan 3 orang pada jenjang S-2, selebihnya pada jenjang yang lebih rendah sehingga pada beberapa jabatan pun masih dijabat oleh pegawai dengan jenjang pendidikan SLTA dan diploma.

Hal tesebut juga dijelaskan oleh Kepala Bagian Organisasi Sekretariat Daerah Kota yang memberikan keterangan bahwa semua Jabatan Fungsional Umum Aparatur Sipil Negara (ASN) sudah jelas nomenklaturnya, jadi sekarang penyebutannya sudah bukan staf lagi, tapi sesuai dengan Analisis Jabatan yang diduduki. Untuk Aparatur Sipil Negara (ASN) yang ada di lingkungan Pemerintah Kota Ternate, kita sudah buat Analisis Beban Kerja (ABK) di tiap-tiap SKPD, jadi dari situ kita bisa melihat SKPD mana yang memang kekurangan pegawai dan SKPD mana yang kelebihan pegawainya. Jangan sampai ada ketimpangan jumlah Pegawai di Pemerintah Kota Ternate. Oleh sebab itu dengan adanya Analisis Beban Kerja yang sesuai dengan Analisis Jabatan (Anjab), maka kita bisa merekrut atau memosisikan setiap aparatur sesuai dengan jumlah yang dibutuhkan serta kesesuaian kualifikasi pendidikannya.

Berdasarkan hasil wawancara di atas, dapat dijelaskan bahwa pemerintah dapat merekrut atau memosisikan setiap aparatur sesuai dengan jumlah yang dibutuhkan serta kesesuaian kualifikasi pendidikannya, hanya saja masih terdapat jabatan yang kosong.Pada Badan Kepegawaian dan Pengembangan Sumber Daya Manusia Daerah Kota Ternate yang terlihat masih banyak jabatan kosong baik jabatan struktural maupun jabatan teknis/administrasi di mana terdapat 65 jabatan tidak terisi penuh karena jumlah pegawai riil hanya sebanyak 45 orang, sehingga jabatan yang kosong dapat berpengaruh pada kinerja Aparatur Sipil Negara (ASN) dalam suatu organisasi, maka kinerja Aparatur Sipil Negara (ASN) menjadi tidak efektif.
Berdasarkan analisis penulis penempatan pegawai harusnya dilakukan dengan menyesuaikan kemampuan atau kecakapan dan/atau keahlian yang dimiliki pegawai dengan posisi atau jabatan yang akan ditempatkan, hal ini perlu untuk diperhatikan karena dapat memengaruhi kualitas kinerja pegawai dalam suatu organisasi.

Selanjutnya, daftar urut kepangkatan BKPSDMD Kota Ternate sudah sesuai dengan golongan dan pangkat, namun ada permasalahan yang terjadi bahwa ada beberapa Jabatan Pelaksana atau Jabatan Fungsional Umum yang belum terisi formasinya, sehingga terjadi kekosongan jabatan serta kekurangan pegawai yang mengakibatkan penempatan pegawai pada BKPSDMD kota Ternate belum berjalan efektif.

\section{Aspek Pengetahuan dan Keterampilan}

Penempatan pegawai harus disesuaikan dengan pengetahuan dan keterampilan dengan bidang kerjanya. Secara teoretis bahwa suatu pekerjaan akan dapat diselesaikan lebih efektif manakala dikerjakan oleh ahlinya, karena itu penempatan pegawai tentunya perlu mempertimbangkan antara keterampilan dan keahlian pegawai dengan bidang kerjanya. Dalam hal penempatan pegawai, kesesuaian pengetahuan dan keterampilan pegawai dengan tugas pokok dan fungsinya harus menjadi pertimbangan penting agar pekerjaan yang diemban dapat diselesaikan dengan baik. Berdasarkan data yang diambil mengenai pejabat eselon yang ada pada BKPSDMD Kota Ternate sampai saat ini jumlah pejabat yang ada pada Badan Kepegawaian dan Pengembangan Sumber Daya Manusia Daerah Kota Ternate berjumlah 19 pejabat namun yang telah mengikuti Diklat PIM II berjumlah 1 pejabat, Diklat PIM III berjumlah 4 pejabat yang telah mengikuti dan 1 pejabat yang belum mengikuti, Diklat Pim IV berjumlah 8 pejabat 
yang telah mengikuti dan 5 pejabat yang belum mengikuti.

Berdasarkan penjelasan di atas diketahui bahwa masih terdapat beberapa pejabat yang belum memenuhi syarat jabatan sehingga akan berpengaruh dalam pelaksanaan pekerjaannya sebagai pejabat eselon yang ada pada BKPSDMD Kota Ternate, hal ini menyebabkan kemampuan yang dimiliki oleh beberapa pejabat yang ada pada BKPSDMD Kota Ternate masih kurang, sehingga peneliti menyimpulkan bahwa penempatan Aparatur Sipil ditinjau dari aspek pengetahuan dan keterampilan masih kurang efektif karena masih ada pejabat yang belum mengikuti Diklat yang merupakan keharusan dalam persyaratan jabatan.

Hal tersebut dibenarkan oleh Kepala Bidang Pengembangan Kompetensi

Aparatur pada Badan Kepegawaian dan Pengembangan Sumber Daya Manusia

Daerah Kota Ternate yang menyatakan benar bahwa dari 19 jumlah pejabat yang ada pada BKPSDMD Kota Ternate hanya 13 pejabat saja yang telah mengikuti Diklat Pim sesuai dengan jabatan yang ditempati, hanya saja para pejabat yang belum mengikuti Diklat dikarenakan Pemerintah Kota Ternate hanya mengadakan Diklat Teknis dan Diklat PIM IV karena masalah anggaran dalam beberapa tahun ini sehingga beberapa pejabat belum dapat diikutsertakan."

Dari uraian di atas dapat dijelaskan bahwa apabila kemampuan pegawai dikaitkan dengan pelaksanaan Diklat Pim sesuai dengan eselonisasi jabatan yang diduduki oleh pegawai, maka saat ini BKPSDMD Kota Ternate masih kurang efektif dalam meningkatkan kemampuan para pegawai sesuai dengan jabatan yang diemban dikarenakan masih terdapat 6 pegawai yang belum mengikuti Diklat Pim sementara yang telah mengikuti adalah sebanyak 13 pegawai.

Dalam hal kemampuan mengarahkan bawahan, menurut Pegawai Jabatan Fungsional Umum di Bidang Penilaian
Kinerja Aparatur dan Penghargaan pada BKPSDMD Kota Ternate yang menyatakan untuk pengarahan dari Pimpinan kami selaku Kepala BKPSDMD Kota Ternate sudah sangat baik dan cepat dimengerti, hanya saja kemampuan dari masing-masing staf atau pegawai yang agak lambat dalam memahami dan menyelesaikan perintah atau pekerjaan yang diberikan, hal ini dikarenakan banyak pegawai yang masih memiliki sifat malas dalam bekerja sehingga pekerjaan yang harus terselesaikan dapat tertunda.

Selanjutnya, pegawai Jabatan Fungsional Umum di Bidang Mutasi dan Promosi pada BKPSDMD Kota Ternate memberikan keterangan bahwa pengarahan yang diberikan dari atasan sudah baik, kami selaku staf atau pegawai BKPSDMD Kota Ternate dapat memahami setiap arahan yang diberikan, contohnya saya sebagai Operator Komputer di Bidang Mutasi dan Promosi menyelesaikan pekerjaan saya sesuai arahan serta tugas pokok dan fungsi, hanya saja ada beberapa tugas tambahan yang saya kerjakan karena ada beberapa jabatan staf yang kosong.

Berdasarkan hasil wawancara tersebut di atas, peneliti menganalisis bahwa meskipun kemampuan dari pejabat sudah sangat memadai, namun karena banyaknya jabatan yang kosong menyebabkan beberapa pegawai kesulitan dalam menyelesaikan pekerjaannya karena mendapatkan tambahan tugas di luar tupoksinya.

\section{Faktor-Faktor yang Memengaruhi}

\section{Efektivitas Penempatan Kerja Aparatur Sipil Negara pada BKPSDMD Kota Ternate}

Berdasarkan hasil wawancara dan pembahasan mengenai efektivitas penempatan aparatur sipil negara ditinjau dari aspek kesesuaian Pendidikan, pengetahuan dan keterampilan, serta pengalaman kerja diketahui bahwa penempatan Aparatur Sipil Negara BKPSDMD Kota Ternate belum sepenuhnya 
efektif. Oleh karena itu perlu dikaji lebih lanjut mengenai faktor-faktor yang memengaruhi atau menjadi penyebab penempatan ASN tersebut belum efektif.

Menurut Kepala Bidang Pengembangan Kompetensi Aparatur pada BKPSDMD Kota Ternate penempatan pegawai harus sesuai dengan kompetensi pegawai atau lebih spesifiknya latar pendidikan pegawai, banyaknya diklat yang diikuti, dan prestasi kerja. Berdasarkan hasil wawancara di atas dapat diketahui bahwa apabila penempatan aparatur negeri sipil tidak sesuai dengan latar belakang pendidikan, pengetahuan dan pengalaman tersebut membuat penempatan tersebut tidak efektif karena tidak memenuhi prinsip penempatan "the right man on the right place" atau tidak menempatkan seseorang di tempat yang tepat untuknya. Kondisi tersebut tidak terlepas dari faktor keterbatasan jumlah sumber daya manusia yang sesuai kualifikasi jabatan tertentu baik secara pendidikan dan pengalaman.

Ketidaksesuaian faktor-faktor di atas bisa kita lihat pada komposisi Pegawai Badan Kepegawaian Daerah di mana berdasarkan Pangkat/Golongan Ruang berjumlah 45 orang dengan komposisi terbanyak adalah pegawai yang memiliki pangkat/golongan Pengatur Muda, yakni 11 orang sementara komposisi terkecil adalah pegawai yang memiliki pangkat/golongan Pembina Utama Muda dan Pembina, yakni 2 orang, hal ini kemudian menunjukkan faktor keterbatasan kuantitas Sumber Daya manusia. Menurut Kepala BKPSDMD Kota Ternate, dalam penerapan the right man in the right place belum berjalan dengan baik karena masih ada keterbatasan pegawai dan adapun kekosongan jabatan. Berkaitan dengan kekosongan jabatan yang terjadi, jika nanti adanya pengangkatan pegawai pada jabatan tersebut diharapkan agar pejabatnya dapat memiliki kompetensi yang sesuai

Berdasarkan hasil wawancara dengan Kepala BKPSDMD Kota Ternate diketahui bahwa masih dibutuhkan banyak pegawai dengan kompetensi yang sesuai dengan kebutuhan. jumlah pegawai yang pendidikannya memenuhi syarat jabatan yang masih sangat sedikit. Hal tersebut dikarenakan banyak pegawai yang belum mampu melanjutkan pendidikannya ke jenjang yang lebih tinggi sebagaimana disyaratkan oleh jabatan. Selain itu walaupun secara jenjang pendidikan sesuai dengan yang disyaratkan namun bidang studinya dan latar belakang pengalamannya tidak sesuai dengan bidang pekerjaannya. Misalnya sarjana keuangan ditempatkan di bagian yang sama sekali tidak berhubungan dengan keuangan. Hal tersebut tentu menyebabkan pegawai tersebut tidak dalam memberikan kinerja yang optimal.

Ketidaksesuaian prestasi akademik atau pendidikan dengan jabatan, ketidaksesuaian pengetahuan dan ketidaksesuaian pengalaman juga kemudian bisa dilihat dari penjelasan mengenai deskripsi BKPSDMD Kota Ternate, di mana keadaan pegawai yang telah mengikuti Pendidikan dan latihan struktural hanya sebanyak sepuluh orang yang kemudian mengindikasikan prestasi akademik dari pegawai.

\section{Aspek Pengalaman}

Pengalaman kerja merupakan salah satu alternatif untuk menentukan seseorang dalam suatu pekerjaan, sebab suatu pekerjaan dikerjakan oleh orang yang mempunyai pengalaman niscaya hasilnya lebih baik. Oleh sebab itu dalam menempatkan pegawai perlu mempertimbangkan pengalaman yang dimiliki, dan atas pengalaman itulah seseorang dapat menyelesaikan tugasnya dengan baik. Berdasarkan wawancara dengan Kepala BKPSDMD Kota Ternate mengatakan bahwa, "kesesuaian penempatan pegawai pada jabatannya dengan pengalaman belum sepenuhnya terpenuhi melainkan baru berjalan sekitar $60 \%$ saja. Di mana sebagian penempatan pegawai belum menyesuaikan sesuai dengan 
latar belakang pendidikannya dikarenakan kurangnya SDM yang ada.

Berdasarkan wawancara di atas, menurut pandangan penulis idealnya, pegawai seharusnya ditempatkan berdasarkan latar belakang bidang Pendidikan yang ditempuhnya akan tetapi pada praktiknya, terdapat beberapa pegawai yang ditempatkan di bidang kerja yang tidak sesuai dengan latar belakang pengalaman dan Pendidikannya.

Menyikapi hal tersebut Kepala BKPSDMD Kota Ternate menyatakan bahwa dari BKPSDMD kami membuat SK penempatan baru agar pegawai menempati jabatan sesuai dengan latar belakang Pendidikan dan pengalamannya. Walaupun pada akhirnya pegawai dibuatkan SK penempatan baru namun karena sementara waktu harus menempati jabatan yang tidak sesuai dengan bidangnya maka kinerja karyawan tersebut menjadi kurang optimal.

Berdasarkan pernyataan tersebut maka bisa diketahui bahwasannya penempatan aparatur negeri sipil berdasarkan pengalaman di BKPSDMD Kota Ternate belum sepenuhnya efektif. Selain itu, kita bisa mengetahui komposisi pegawai di BKPSDMD Kota ternate berdasarkan masa kerjanya, di mana pegawai yang memiliki masa kerja $0-5$ Tahun sebanyak 16 orang, 6-10 Tahun sebanyak 9 orang, 11-15 Tahun sebanyak 8 orang, 16-20 Tahun sebanyak 6 orang, dan 21-30 Tahun sebanyak 5 orang, dari komposisi tersebut kita bisa mengetahui bagaimana pengalaman kerja pegawai di BKPSDMD Kota ternate di mana sebagian besar pegawai memiliki masa kerja yang relati rendah, yaitu 0-5 Tahun.

\section{SIMPULAN}

Berdasarkan hasil penelitian dan pembahasan, ditarik simpulan bawa penempatan Aparatur Sipil Negara Aparatur Sipil Negara Badan Kepegawaian dan

Pengembangan Sumber Daya Manusia Daerah (BKPSDMD) Kota Ternate belum sepenuhnya efektif. Ditinjau dari aspek pendidikan, penempatan ASN belum sesuai dengan jenjang dan bidang studi yang disyaratkan jabatan, begitu pun dengan kesesuaian pengetahuan, keterampilan dan pengalaman yang belum sepenuhnya sesuai dengan syarat jabatan.

Faktor-faktor yang memengaruhi penempatan ASN di BKPSDMD Kota Ternate Belum efektif, di mana dari 6 faktor yang dikemukakan oleh Siswanto (2002) diketahui bahwa faktor yang paling dominan memengaruhi efektivitas penempatan pegawai di BKPSDMD Kota ternate adalah faktor ketidaksesuaian prestasi akademik atau pendidikan dengan jabatan, ketidaksesuaian pengetahuan, ketidaksesuaian pengalaman dengan jabatan dan faktor keterbatasan kuantitas sumber daya manusia yang memenuhi persyaratan jabatan tertentu.

\section{SARAN}

Berdasarkan simpulan yang telah dipaparkan, maka Penulis mengajukan beberapa saran sebagai berikut.

1. Badan Kepegawaian dan Pengembangan Sumber Daya Manusia Daerah

(BKPSDMD) Kota Ternate disarankan untuk melakukan penataan ASN sesuai dengan bidang pendidikan, pengetahuan, keterampilan dan juga pengalamannya. Upaya yang dapat ditempuh adalah dengan menyelenggarakan serangkaian program pendidikan dan latihan secara sistematis. Selain itu BKPSDMD Kota Ternate disarankan lebih tegas dalam mendorong ASN untuk mengikuti Diklat yang disyaratkan.

2. Peneliti selanjutnya disarankan untuk mengkaji topik yang sama dalam ruang lingkup yang lebih luas serta dengan menggunakan metode penelitian yang berbeda. Dari hasil penelitian diketahui bahwa faktor yang memengaruhi efektivitas penempatan pegawai adalah 
faktor pendidikan, pengalaman dan keterbatasan ketersediaan sumber daya manusia yang sesuai kualifikasi, peneliti selanjutnya disarankan untuk meneliti pengaruh faktor-faktor tersebut terhadap efektivitas penempatan ASN agar dapat memperkuat hasil penelitian ini.

\section{DAFTAR PUSTAKA}

Arikunto, Suharsimi. 2010. Prosedur Penelitian Suatu Pendekatan Praktik. Rineka Cipta. Jakarta.

Berg, Bruce Lawrence.2001. Qualitatuve Research Methods for the social sciences. United States of America: Pearson

Blau, Peter M, Marshall W. Meyer, R.Yusuf, Gary (Penerjemah). 2000. Birokrasi Dalam Masyarakat Modern. UI Press. Jakarta.

Cardoso, Faustino. Manajemen Sumber Daya Manusia. Jakarta: Badan Penerbit IPWI

Danim, Sudarwan. 2002. Menjadi Peneliti kualitatif. CV. Pustaka Setia. Bandung.

Dessler, Gary. 2005. Manajemen Sumber Daya Manusia. Human Resource Management. (Penerjemah: Benyamin Molan). PT. Prenhallindo. Jakarta.

Gibson, James L. Ivancevich, Donnely, John M Donelly, James H.JR. 1996. Organisasi: Perilaku, Struktur, proses. Jilid 1 dan Jilid 2 (Alih Bahasa: Nunuk Adiarna. Editor Lyndon Saputra) Binarupa Aksara. Jakarta.

--------, Ivancevich dan Donnely., 1997, Organisasi dan Manajemen Cetakan Keempat, Erlangga, Jakarta

Gulo, W. 2007. Metodologi Penelitian. Grasindo. Jakarta.

Gomes, Faustino Cardoso, 2005, Manajemen Sumber Daya Manusia, Andi Offset, Yogyakarta.
Handayaningrat, Suwarno. 1994. Pengantar Studi Ilmu Administrasi dan Manajemen. Haji Masagung. Jakarta.

Indrawijaya, Adam. 2002. Perilaku Organisasi. Sinar Baru Algensindo. Bandung.

\section{Teori, Perilaku dan Budaya}

$$
\text { Bandung. }
$$

Organisasi. Refika Aditama.

Keban, Yeremias, T. 2008. Peningkatan Kinerja Pelayanan Publik melalui Accountable Management. Journal PSPK. Jakarta

Koswara, E, 2001, Otonomi Daerah untuk Demokrasi dan Kemandirian Rakyat, Yayasan PARIBA, Jakarta.

Mahmudi. 2010. Manajemen Kinerja Sektor Publik. Sekolah Tinggi Ilmu Manajemen YKPN. Yogyakarta.

Mahsun, Mohammad. 2014. Pengukuran Kinerja Sekor Publik. Yogyakarta: BPFE

Mangkunegara, Anwar Prabu. 2005. Sumber Daya Manusia Perusahaan.

Remaja Rosdakarya. Bandung.

2008. Manajemen Sumber Daya Manusia Perusahaan. Remaja Rosdakarya. Bandung.

2010. Evaluasi Kinerja SDM. PT. Refika Aditama. Bandung.

Mangkuprawira, S., dan A.V. Hubeis, (2007) Manajemen Mutu Sumber Daya Manusia. Penerbit Ghalia Indonesia, Bogor

Moleong, Lexy J. Moleong, Lexy. 2012. Metodologi Penelitian Kualitatif. PT. Remaja Rosdakarya. Bandung.

Nazir, Mohammad. 2005. Metode Penelitian. Ghalia Indonesia. Bogor.

Ndraha, Taliziduhu. 1999, Pengantar Teori Pengembangan Sumber Daya Manusia, PT. Rineka Cipta, Jakarta. 2005. Kybernologi (Ilmu Pemerintahan Baru) Jilid I,II, Rineka Cipta. Jakarta 
Notoatmodjo, Soekidjo, 2008. Pendidikan dan Pelatihan, Penerbit FKM-UI, Jakarta.

Panggabean, Sibarani Mutiara. 2004. Manajemen Sumber Daya Manusia,: Ghalia Indonesia, Bogor Selatan

Pasolong, Harbani. 2012. Teori Administrasi Publik. ALFABETA. Bandung.

Robbins, S.P., 2001, Perilaku Organisasi, Edisi Bahasa Indonesia,Jilid I dan

II,Prinhalindo, Jakarta.

Sedarmayanti, 2004. Good Governance (Kepemerintahan yang Baik) Dalam

Rangka Otonomi Daerah, Upaya Membangun Organisasi Efektif dan

Efisien Melalui Restrukturisasi dan Pemberdayaan. CV.Mandar Maju. Bandung.

2009. Sumber Daya Manusia dan Produktivitas Kerja. CV. Mandar Maju. Bandung

Siagian, Sondang P. 1988. Teori dan Praktik Kepemimpinan, Bina Aksara. Jakarta.

2000. Peranan Staf dalam Manajemen. Bumi Aksara. Jakarta.

2006. Filsafat Administrasi, Gunung Agung. Jakarta.

2008. Organisasi Kepemimpinan \& Perilaku Administrasi, PT. Toko Gunung Agung; Jakarta.

2009, Manajemen Sumber Daya Manusia, Bumi Aksara. Jakarta.

Simamora, Henry. 2010. Manajemen Sumber Daya Manusia, Edisi 2, STIE YKPN. Yogyakarta.

Sigit, Soehardi. 2003. Pengantar Metodologi Penelitian Sosial-Bisnis-Manajemen. Pena Persada Offset. Yogyakarta.

Sinambela, Lijan Poltak 2012. Kinerja Pegawai Teori Pengukuran dan Implikasi. Yogyakarta: Graha Ilmu

Siswanto, Bedjo. 2003. Manajemen Tenaga Kerja; Ancaman Dalam Pendayagunaan dan Pengembangan Unsur Tenaga Kerja. Bandung: Sinar Baru
Sugiyono. 2008. Metode Penelitian Kuantitatif, Kualitatif dan R\&D. Alfabeta. Bandung.

2012. Memahami Penelitian Kualitatif. Alfabeta. Bandung.

Suradinata, Ermaya. 1996. Manajemen Sumber Daya Manusia Orientasi Masa Depan, Ramadhan, Bandung. 2013. Analisis Kepemimpinan Strategi Pengambilan Keputusan, ASOCA,

Ability, Strength, Opportunities, Culture, Agility, Alqaprint Jatinangor, Sumedang, Bandung.

Sutrisno, Edy. 2010. Manajemen Sumber Daya Manusia. Kencana Prenada Media Group. Jakarta

Soekanto, Soerjono. 1990. Sosiologi Suatu Pengantar. PT Raja Grafindo Persada. Jakarta.

Soetopo, Hendyat. 2010. Perilaku Organisasi Teori dan Praktik dalam Bidang Pendidikan. PT Remaja Rosdakarya. Bandung.

Steers, Richard M. 1985. Efektivitas Organisasi: Kaidah Perilaku, Erlangga, Jakarta.

Sudarmanto. 2009. Kinerja dan Pengembangan Kompetensi Sumber Daya Manusia (Teori, Dimensi, Pengukuran dan Implementasi Dalam Organisasi). Yogyakarta: Pustaka Belajar

Suwatno, dan Tjutju Yuniarsih. 2013. Manajemen Sumber Daya Manusia. Bandung: Alfabeta

Thoha, Miftah. 2006. Perilaku Organisasi: Konsep dasar dan Aplikasi. Jakart: Rajawali Pers.

2008. Deregulasi dan Debirokratisasi dalam Upaya Peningkatan Mutu Pelayanan Masyarakat, Pembangunan Administrasi di Indonesia.: LP3ES, Jakarta

Uno, Hamzah B dan Nina Lamatenggo.2012. Teori Kinerja dan Pengukurannya. Jakarta: PT Bumi Aksara

Wasistiono, Sadu., Irwan Tahir., 2007, Prospek Pengembangan Desa, Penerbit: Fokusmedia, Bandung 
Westra, P. Sutarto, Syamsi. 1989. Ensiklopedia Administrasi. CV. Haji Masagung. Jakarta.

Wibowo. 2012. Manajemen Kinerja. Jakarta: PT

Rajagrafindo Persada

\section{Peraturan Perundang-Undangan}

Undang-Undang Dasar Negara Republik Indonesia 1945

Undang-Undang Nomor 23 Tahun 2014 tentang Pemerintah Daerah

Undang-Undang Nomor 5 Tahun 2014 tentang Aparatur Sipil Negara

Undang-Undang Nomor 11 Tahun 1999 tentang Pembentukan Kota madya Ternate

Peraturan Presiden Nomor 81 Tahun 2010 tentang Grand Design Reformasi Birokrasi 2010-2025

Peraturan Pemerintah Nomor 11 Tahun 2017 tentang Manajemen Pegawai Negeri Sipil

Peraturan Pemerintah Nomor 41 Tahun 2007 tentang Organisasi Perangkat Daerah

Peraturan Wali Kota Ternate Nomor 17 Tahun 2016 tentang Tugas dan Fungsi Badan

Kepegawaian dan Pengembangan Sumber Daya Manusia Daerah Kota

Ternate 


\section{Visioner}

Vol. $12 \backslash$ No. $1 \backslash$ Januari 2020 